\title{
Radioactivity of honey from northern Poland
}

\author{
Alicja Boryło $^{1} \cdot$ Grzegorz Romańczyk $^{1} \cdot$ Jarosław Wieczorek ${ }^{1} \cdot$ Dagmara Strumińska-Parulska $^{1} \cdot$ Marcin Kaczor $^{1}$
}

Received: 7 September 2018 / Published online: 21 November 2018

(c) The Author(s) 2018

\begin{abstract}
This work shows significant variations in the values of ${ }^{210} \mathrm{Po}$ in different analyzed Polish voivodeships. Statistical analysis of ${ }^{210} \mathrm{Po}$ activity concentrations in honey samples showed significant differences between place of honey collecting, kind of honey and morphological structure of plants from which bees collected nectar.
\end{abstract}

Keywords Polonium $\cdot$ Honey $\cdot$ Annual effective dose $\cdot$ Industry $\cdot$ Tomentose $\cdot$ Northern Poland

\section{Introduction}

Honey is produced by honeybees from nectar of different plants, as well as from honeydew. As a foodstuff used for healing purposes, honey must be free of any of objectionable contents, and it should contain only small amounts of pollutants [1]. Environmental samples are complex most often in terms of composition and structure, very often heterogeneous and sometimes variable over time, resulting in lack of repeatability at sampling due to rapid changes in material being analyzed. Bioindicators are organisms used as an indicator of the state of the environment. These are species with a low tolerance index, or in a specific way responsive to the substance. Honey is a popular bioindicator. Bees collecting nectar, pollen and honeydew are often exposed to harmful substances planted on plants used in agriculture and carry these contaminants on the body surface to the hive, and as a consequence the impurities get into the honey. The results showed that trace element concentrations in the honeys from different regions generally reflect the degree of trace element contamination of the environment [1].

Bee honey can be contaminated by various treatments related to apiculture and apiculture itself as well as by xenobiotics in the environment. Taking into account the fact that bees use the benefits of a radius of up to $3 \mathrm{~km}$ from the hive, the origin of the nectar can be determined with great

Alicja Boryło

alicja.borylo@ug.edu.pl

1 Faculty of Chemistry, University of Gdańsk, Wita Stwosza 63, 80-308 Gdańsk, Poland accuracy. With that in mind, bee products can be used as indicators of environmental pollution in a given area.

Research and evaluation of radiological conditions existing in the environment and the ability to track and predict the changes that may occur in it as a result of human activity are significant elements of population exposure control. This exposure is determined by the size of the effective dose which people receive from all sources and types of ionizing radiation during the year. The largest share $(73.8 \%)$ in the value of the effective dose received by a statistical Pole is natural radiation [2]. Among the sources which have an impact on environmental pollution by natural radionuclides are: activities of mining and power industry and the presence of various types of landfills, fertilization; exhalation of radon ${ }^{222} \mathrm{Rn}$ from the surface of the earth and building materials [2-8].

The presence of radionuclides can pose a health risk for humans but their presence in honey have not been studied much. The main aim of this study was determination of ${ }^{210} \mathrm{Po}$ concentration as well as calculation of annual effective dose for ${ }^{210} \mathrm{Po}$ from honey consumption in honey samples collected by courtesy of beekeepers from northern Poland. Moreover, the aim of this work was the diversification of ${ }^{210}$ Po sources in the analyzed honey samples, confirmation of the potential contaminants of the increased levels of natural radionuclides and morphological structure of plants, as well as indication of the usefulness of honeys as bioindicators of environmental pollution. 


\section{Methods and materials}

140 different honey samples obtained from private apiaries of northern Poland were examined. 31, 30, 21, 27 and 31 honey samples respectively were obtained by courtesy of beekeepers or purchased in the area of West Pomeranian Voivodeship, Pomeranian Voivodeship, Podlaskie Voivodeship, WarmianMasurian Voivodeship and Kuyavian-Pomeranian Voivodeship between May and October 2017.

About $10 \mathrm{~g}$ samples of honey were weighed, added with known amount of ${ }^{209}$ Po tracer and dissolved in $100 \mathrm{ml}$ of $1 \mathrm{M}$ $\mathrm{HCl}$. After $1 \mathrm{~h}$ of stirring on magnetic stirrer, samples were filtered and diluted by addition of $400 \mathrm{ml} \mathrm{H}_{2} \mathrm{O}$. The obtained

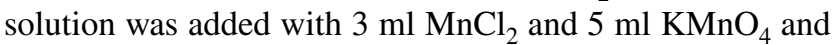
$\mathrm{pH}$ was set to 9 by addition of ammonia. After $1 \mathrm{~h}$ of stirring on magnetic stirrer, samples were left overnight to allow complete precipitation of $\mathrm{MnO}_{2}$. The precipitate was collected by centrifugation (4000 RPM, $5 \mathrm{~min}$ ), dissolved in $15 \mathrm{ml}$ of $1 \mathrm{M}$ $\mathrm{HCl}$ with a drop of $\mathrm{H}_{2} \mathrm{O}_{2}$ then evaporated to near dryness. The remains of organic matrix were decomposed by subsequent evaporation to wet salts with $20 \mathrm{ml}$ of concentrated $\mathrm{HNO}_{3}$ and then $20 \mathrm{ml}$ of concentrated $\mathrm{HCl}$. Finally the residue was dissolved in $15 \mathrm{ml}$ of $0.5 \mathrm{M} \mathrm{HCl}$ and after addition of $0.05 \mathrm{~g}$ of ascorbic acid, solution was transferred to autodeposition cell. Polonium was deposited on silver in time of $1.5 \mathrm{~h}$ with continuous stirring. Obtained polonium was counted by alpha spectrometry between 2 and 6 days.

The activities of ${ }^{210} \mathrm{Po}$ were measured using an alpha spectrometer (Alpha Analyst S470) equipped with a surface barrier PIPS detector with an active surface of 300-450 $\mathrm{mm}^{2}$ placed in a vacuum chamber connected to a 1024 multichannel analyzer (Canberra-Packard, USA). Detector yield ranged from 0.30 to 0.40 . In most of the used detectors with the surface of $300-450 \mathrm{~mm}^{2}$ the resolution was $17-18 \mathrm{keV}$. Minimum detectable activity (MDA) for ${ }^{210} \mathrm{Po}$ was $0.003 \mathrm{mBq} \mathrm{g}^{-1}$. The accuracy and precision of the radiochemical method were estimated to be less than $7 \%$ by participation in international intercomparative exercises and analysis of IAEA materials (IAEA-327, 384, 385, 414, IAEA-TEL-2011-03 and MODAS-2015). The precision between subsamples was estimated to be less than $3 \%$ for all analyzed radioisotopes. ${ }^{210}$ Po activities were corrected for decay between the time of deposition on silver discs and the time of measurement on alpha spectrometer. On the basis of the ${ }^{210} \mathrm{Po}$ concentration and the average honey consumption in Poland $(0.61 \mathrm{~kg} /$ person$)$, the so-called effective annual dose from honey consumption was calculated according to Meli and co-workers [9]:

$D_{\text {Po-210 }}=Q \cdot C_{\text {Po-210 }} \cdot I$

where $D_{\mathrm{Po}-210}$ - annual effective dose $\left(\mu \mathrm{Sv} \operatorname{rok}^{-1}\right), Q$-conversion factor which is $1.2, C_{\mathrm{Po}-210}$-concentration of ${ }^{210} \mathrm{Po}$ $\left(\mathrm{Bq} \mathrm{kg}^{-1}\right), I$-average honey consumption.

\section{Results and discussion}

The results of ${ }^{210} \mathrm{Po}$ concentration in honey samples collected from West Pomeranian Voivodeship, Pomeranian Voivodeship, Podlaskie Voivodeship, WarmianMasurian Voivodeship and Kuyavian-Pomeranian Voivodeship differed in the range between $0.009 \pm 0.001$ and $0.328 \pm 0.013 \mathrm{~Bq} \mathrm{~kg}^{-1}$ (with the average value $0.074 \pm 0.055 \mathrm{~Bq} \mathrm{~kg}^{-1}$ ) (Table 1 and Fig. 1). The values of effective annual dose from honey consumption for analyzed voivodeships were from $0.006 \pm 0.001$ to $0.240 \pm 0.009 \mu \mathrm{Sv}$ year $^{-1}$ (with the mean value $0.054 \pm 0.041 \mu \mathrm{Sv}$ year $\left.^{-1}\right)$.

The results of ${ }^{210} \mathrm{Po}$ concentration and effective annual dose from honey consumption in West Pomeranian Voivodeship were presented in Table 1 and ranged between $0.011 \pm 0.002$ and $0.157 \pm 0.012 \mathrm{~Bq} \mathrm{~kg}^{-1}$ (with the average value $0.068 \pm 0.045 \mathrm{~Bq} \mathrm{~kg}^{-1}$ ), while values of effective annual dose from honey consumption varied from $0.008 \pm 0.002$ to $0.115 \pm 0.009 \mu \mathrm{Sv}$ year $^{-1}$ (with the average value $0.047 \pm 0.033 \mu \mathrm{Sv}$ year $^{-1}$ ) (Fig. 1). The higher values of ${ }^{210}$ Po concentrations and effective annual dose from honey consumption (between $0.099 \pm 0.006$ and $0.157 \pm 0.012 \mathrm{~Bq} \mathrm{~kg}^{-1}$ and between $0.073 \pm 0.004$ and $0.115 \pm 0.009 \mu \mathrm{Sv}$ year $^{-1}$ respectively) were found near Szczecin city, where chemical plant "Fosfan S.A." is situated. "Fosfan S.A." manufactures, sells, distributes, and exports compound agricultural fertilizers and gardening fertilizers. A lot of authors show that chemical industry connected with production of fertilizers for agriculture provides higher activities of natural radionuclides [10-18]. The higher ${ }^{210} \mathrm{Po}$ concentration and effective dose were observed also for samples collected near phosphogypsum heap in Police (from $0.123 \pm 0.004$ to $0.132 \pm 0.017 \mathrm{~Bq} \mathrm{~kg}^{-1}$ and from $0.090 \pm 0.003$ to $0.097 \pm 0.012 \mu \mathrm{Sv}$ year $\left.^{-1}\right)$. Other authors suggests that higher content of polonium and uranium in various components of environment can be considered as an effect of their transfer from heap to plants and soils caused by leaching and lixiviation $[15,19,20]$.

Generally, the average ${ }^{10} \mathrm{Po}$ concentrations and effective annual dose from honey consumption were higher for industrial areas of this province $\left(0.128 \pm 0.021 \mathrm{~Bq} \mathrm{~kg}^{-1}\right.$ and $0.094 \pm 0.015 \mu \mathrm{Sv}$ year $^{-1}$ respectively) than for non-industrial areas $\left(0.053 \pm 0.037 \mathrm{~Bq} \mathrm{~kg}^{-1}\right.$ and $0.036 \pm 0.025 \mu \mathrm{Sv}$ year $^{-1}$ respectively) (Table 2) (Fig. 2).

The results of ${ }^{210} \mathrm{Po}$ concentration and effective annual dose from honey consumption in Pomeranian Voivodeship were presented in Table 1. The ${ }^{210} \mathrm{Po}$ concentration in this province was between $0.016 \pm 0.002$ and $0.238 \pm 0.006 \mathrm{~Bq} \mathrm{~kg}^{-1}$ (with the average value $0.090 \pm 0.072 \mathrm{~Bq} \mathrm{~kg}^{-1}$ ) (Fig. 1), while values 
Table $1{ }^{210}$ Po concentration and annual effective dose from the honey consumption in honey samples taken from KuyavianPomeranian Voivodeship (KP), Podlaskie Voivodeship (PD), Pomorskie Voivodeship (PM), Warmian-Masurian Voivodeship (WM) and West Pomeranian Voivodeship (WP)

\begin{tabular}{|c|c|c|c|c|c|c|c|}
\hline \multirow[t]{3}{*}{ Kind of honey } & \multirow[t]{3}{*}{$\mathrm{n}$} & \multicolumn{3}{|c|}{${ }^{210} \mathrm{Po}$ concentration $\left(\mathrm{Bq} \mathrm{kg}{ }^{-1}\right)$} & \multicolumn{3}{|c|}{ Effective dose $\left(\mu \mathrm{Sv}\right.$ year $\left.{ }^{-1}\right)$} \\
\hline & & \multicolumn{2}{|l|}{ Value } & \multirow[t]{2}{*}{ mean $\pm \mathrm{SD}$} & \multicolumn{2}{|l|}{ Value } & \multirow[t]{2}{*}{ Mean \pm SD } \\
\hline & & Min & $\operatorname{Max}$ & & Min & Max & \\
\hline \multicolumn{8}{|c|}{ Kuyavian-Pomeranian Voivodeship } \\
\hline All & 31 & 0.009 & 0.208 & $0.092 \pm 0.067$ & 0.007 & 0.152 & $0.067 \pm 0.049$ \\
\hline Honeydew & 13 & 0.073 & 0.208 & $0.157 \pm 0.039$ & 0.053 & 0.152 & $0.115 \pm 0.029$ \\
\hline Nectar & 18 & 0.009 & 0.127 & $0.045 \pm 0.036$ & 0.007 & 0.093 & $0.033 \pm 0.026$ \\
\hline \multicolumn{8}{|c|}{ Podlaskie Voivodeship } \\
\hline All & 21 & 0.013 & 0.109 & $0.053 \pm 0.031$ & 0.010 & 0.080 & $0.039 \pm 0.023$ \\
\hline Honeydew & 8 & 0.058 & 0.109 & $0.087 \pm 0.022$ & 0.042 & 0.080 & $0.064 \pm 0.016$ \\
\hline Nectar & 13 & 0.013 & 0.046 & $0.032 \pm 0.010$ & 0.010 & 0.034 & $0.023 \pm 0.007$ \\
\hline \multicolumn{8}{|c|}{ Pomorskie Voivodeship } \\
\hline All & 30 & 0.016 & 0.238 & $0.090 \pm 0.072$ & 0.012 & 0.174 & $0.066 \pm 0.053$ \\
\hline Honeydew & 12 & 0.064 & 0.238 & $0.151 \pm 0.059$ & 0.047 & 0.174 & $0.111 \pm 0.043$ \\
\hline Nectar & 18 & 0.016 & 0.198 & $0.049 \pm 0.048$ & 0.012 & 0.145 & $0.036 \pm 0.035$ \\
\hline \multicolumn{8}{|c|}{ Warmian-Masurian Voivodeship } \\
\hline All & 27 & 0.012 & 0.104 & $0.060 \pm 0.031$ & 0.009 & 0.082 & $0.044 \pm 0.023$ \\
\hline Honeydew & 10 & 0.075 & 0.104 & $0.089 \pm 0.010$ & 0.055 & 0.076 & $0.065 \pm 0.008$ \\
\hline Nectar & 17 & 0.012 & 0.094 & $0.042 \pm 0.025$ & 0.009 & 0.082 & $0.032 \pm 0.020$ \\
\hline \multicolumn{8}{|c|}{ West Pomeranian Voivodeship } \\
\hline All & 31 & 0.011 & 0.157 & $0.068 \pm 0.045$ & 0.008 & 0.115 & $0.047 \pm 0.033$ \\
\hline Honeydew & 10 & 0.082 & 0.157 & $0.119 \pm 0.025$ & 0.053 & 0.115 & $0.083 \pm 0.021$ \\
\hline Nectar & 21 & 0.011 & 0.127 & $0.043 \pm 0.030$ & 0.008 & 0.093 & $0.030 \pm 0.022$ \\
\hline
\end{tabular}

$n$ quanity of samples
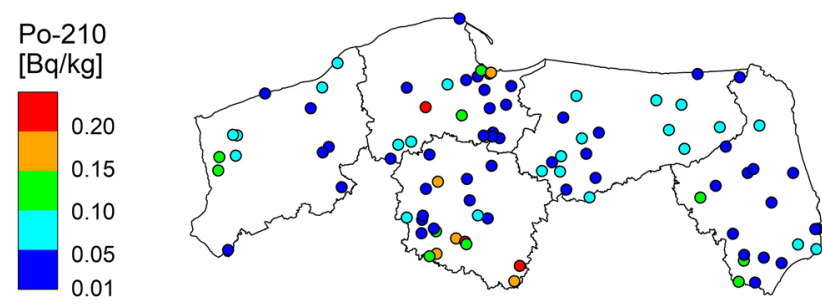

Fig. $1{ }^{210} \mathrm{Po}$ concentration in analyzed honey samples taken from Kuyavian-Pomeranian Voivodeship (KP), Podlaskie Voivodeship (PD), Pomorskie Voivodeship (PM), Warmian-Masurian Voivodeship (WM) and West Pomeranian Voivodeship (WP)

of effective annual dose from honey consumption ranged from $0.012 \pm 0.002$ to $0.174 \pm 0.004 \mu \mathrm{Sv}$ year $^{-1}$ (with the average value $0.066 \pm 0.053 \mu \mathrm{Sv}$ year ${ }^{-1}$ ). The average ${ }^{10} \mathrm{Po}$ concentrations and effective annual dose from honey consumption were higher for industrial areas of this province $\left(0.175 \pm 0.041 \mathrm{~Bq} \mathrm{~kg}^{-1}\right.$ and $0.129 \pm 0.030 \mu \mathrm{Sv}$ year $^{-1}$ respectively) than for non-industrial areas $\left(0.040 \pm 0.021 \mathrm{~Bq} \mathrm{~kg}^{-1}\right.$ and $0.030 \pm 0.015 \mu \mathrm{Sv}$ year $^{-1}$ respectively) (Table 2, Fig. 2). The higher values of ${ }^{210} \mathrm{Po}$ concentrations and effective dose were measured in this region around phosphogypsum waste heap in Wiślinka and varied from $0.123 \pm 0.013$ to $0.207 \pm 0.007 \mathrm{~Bq} \mathrm{~kg}^{-1}$ and from $0.090 \pm 1.010$ to $0.152 \pm 0.005 \mu \mathrm{Sv}$ year $^{-1}$ respectively. Long-term studies of the impact of phosphogypsum heap in Wiślinka have proved that this area can be a threat to the surrounding environment. Detailed studies of Wiślinka phophogypsum heap were described by Boryło and co-workers [6-8, 21] and Olszewski and coworkers [22, 23]. In this province higher ${ }^{210} \mathrm{Po}$ concentration and effective dose were also measured in Gdańsk city, where the petrochemical industry is developing (from $0.128 \pm 0.005$ to $0.142 \pm 0.012 \mathrm{~Bq} \mathrm{~kg}^{-1}$ and from $0.094 \pm 0.004$ to $0.104 \pm 0.009 \mu \mathrm{Sv}$ year $^{-1}$ respectively.

The results of ${ }^{210} \mathrm{Po}$ concentration and effective annual dose from honey consumption in Warmian-Masurian Voivodeship were presented in Table 1 . The ${ }^{210} \mathrm{Po}$ concentration in this province was between $0.012 \pm 0.001$ and $0.104 \pm 0.008 \mathrm{~Bq} \mathrm{~kg}^{-1}$ (with the average value $0.060 \pm 0.031 \mathrm{~Bq} \mathrm{~kg}^{-1}$ ) (Fig. 1), while values of effective annual dose from honey consumption ranged from $0.009 \pm 0.001$ to $0.082 \pm 0.012 \mu \mathrm{Sv}$ year $^{-1}$ (with the average value $0.044 \pm 0.023 \mu \mathrm{Sv}$ year ${ }^{-1}$ ). The similar values of ${ }^{210} \mathrm{Po}$ concentration and effective annual dose from honey consumption were obtained in Podlaskie Voivodeship and presented in Table 1 . The ${ }^{210} \mathrm{Po}$ concentration in this province was between $0.013 \pm 0.002$ and $0.109 \pm 0.007 \mathrm{~Bq} \mathrm{~kg}^{-1}$ (with the average value $0.053 \pm 0.031 \mathrm{~Bq} \mathrm{~kg}^{-1}$ ) (Fig. 1), 
Table $2{ }^{210}$ Po concentration and annual effective dose from the honey consumption in honey samples taken from industrial and non-industrial areas of Kuyavian-Pomeranian Voivodeship (KP), Pomorskie Voivodeship (PM) and West Pomeranian Voivodeship (WP)

\begin{tabular}{|c|c|c|c|c|c|c|c|}
\hline \multirow[t]{3}{*}{ Kind of area } & \multirow[t]{3}{*}{$\mathrm{n}$} & \multicolumn{3}{|c|}{${ }^{210} \mathrm{Po}$ concentration $\left(\mathrm{Bq} \mathrm{kg}^{-1}\right)$} & \multicolumn{3}{|c|}{ Effective dose $\left(\mu \mathrm{Sv}\right.$ year $\left.^{-1}\right)$} \\
\hline & & \multicolumn{2}{|l|}{ Value } & \multirow[t]{2}{*}{ Mean \pm SD } & \multicolumn{2}{|l|}{ Value } & \multirow[t]{2}{*}{ Mean \pm SD } \\
\hline & & Min & Max & & Min & $\operatorname{Max}$ & \\
\hline \multicolumn{8}{|c|}{ Kuyavian-Pomeranian Voivodeship } \\
\hline Industrial & 12 & 0.101 & 0.199 & $0.156 \pm 0.031$ & 0.074 & 0.146 & $0.114 \pm 0.023$ \\
\hline Non-industrial & 19 & 0.009 & 0.208 & $0.052 \pm 0.050$ & 0.007 & 0.152 & $0.038 \pm 0.036$ \\
\hline \multicolumn{8}{|c|}{ Pomeranian Voivodeship } \\
\hline Industrial & 11 & 0.123 & 0.238 & $0.175 \pm 0.041$ & 0.090 & 0.174 & $0.129 \pm 0.030$ \\
\hline Non-industrial & 19 & 0.016 & 0.095 & $0.040 \pm 0.021$ & 0.012 & 0.070 & $0.030 \pm 0.015$ \\
\hline \multicolumn{8}{|c|}{ West Pomeranian Voivodeship } \\
\hline Industrial & 6 & 0.099 & 0.157 & $0.128 \pm 0.021$ & 0.073 & 0.115 & $0.094 \pm 0.015$ \\
\hline Non-industrial & 25 & 0.011 & 0.132 & $0.053 \pm 0.037$ & 0.008 & 0.097 & $0.036 \pm 0.025$ \\
\hline
\end{tabular}

$n$ quanity of samples

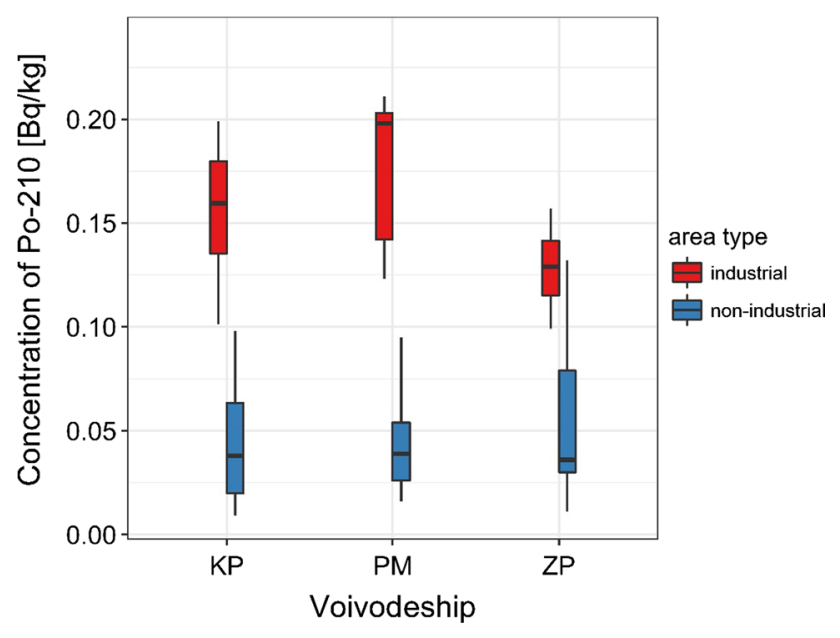

Fig. $2{ }^{210} \mathrm{Po}$ concentration in honey samples taken from industrial and non-industrial areas of Kuyavian-Pomeranian Voivodeship (KP), Pomorskie Voivodeship (PM) and West Pomeranian Voivodeship (WP)

while values of effective annual dose from honey consumption ranged from $0.010 \pm 0.002$ to $0.080 \pm 0.005 \mu \mathrm{Sv}$ year $^{-1}$ (with the average value $0.039 \pm 0.023 \mu \mathrm{Sv}$ year $^{-1}$ ). Due to the values of the natural environment the region of Warmian-Masurian voivodeship is often called the "green lungs" of Poland. It results among others, from the low level of industrialization in the voivodeship, which is primarily limited to agricultural and forestry production. Other branches of industry are located mainly in Olsztyn and Elblag - the two largest cities in the region. Also the assessment of the environmental condition of the Podlaskie voivodeship, which has unique natural values, indicates that it is a region with the highest environmental quality standards in Poland. In both voivodeships, no area was found for which higher concentrations of ${ }^{210} \mathrm{Po}$ were noted. It seems, however, that slightly higher ${ }^{210}$ Po concentrations were measured among plants covered with thick, tangled hairs that cover the leaves, stem and fruit (e.g. raspberry, acacia, yellow sweet clover). On the other hand, the above mentioned plants belong to collective clade [24]. This clade is called the rosids and is a member of a large clade (monophyletic group) of flowering plants $[25,26]$. They are classified according to their cup and crown or single or disappearing flower. The average values of ${ }^{210} \mathrm{Po}$ concentration and effective dose for these plants were $0.058 \pm 0.020 \mathrm{~Bq} \mathrm{~kg}^{-1}$ and $0.045 \pm 0.019 \mu \mathrm{Sv}_{\text {year }}{ }^{-1}$ for Warmian-Masurian Voivodeship and $0.040 \pm 0.005 \mathrm{~Bq} \mathrm{~kg}^{-1}$ and $0.029 \pm 0.004 \mu \mathrm{Sv}$ year $^{-1}$ for Podlaskie Voivodeship (Table 3, Fig. 3). The smaller values of analyzed ${ }^{210} \mathrm{Po}$ were observed for plants not covered by tomentose and they do not belong to rosids $\left(0.031 \pm 0.022 \mathrm{~Bq} \mathrm{~kg}^{-1}\right.$ and $0.023 \pm 0.016 \mu \mathrm{Sv}$ year $^{-1}$ for Warmian-Masurian Voivodeship and $0.026 \pm 0.008 \mathrm{~Bq} \mathrm{~kg}^{-1}$ and $0.019 \pm 0.006 \mu \mathrm{Sv}_{\mathrm{year}}{ }^{-1}$ for Podlaskie Voivodeship) (Table 3, Fig. 3). This effect was also observed for Kuyavian-Pomeranian Voivodeship and West Pomeranian Voivodeship (Table 3, Fig. 3). Also research conducted in northern Poland confirm that plants that are tomentose or hairs covered have ability to accumulate higher amounts of polonium and uranium [19].

However, it should be remembered that honey may not be the most sensitive tool for evaluating environmental contamination with heavy metals due to the low concentration present, and the great variability caused by several factors, e.g. botanical origin, floral density, season of the year and rainfall [1]. Also in the territories of these voivodeships, higher concentrations of ${ }^{210} \mathrm{Po}$ were measured for honeydew samples. This is also noticeable for all other provinces. Honeydew honey arises from the juice of some trees. This is a viscous, sweet discharge mainly in summer in the form of droplets on trees, secreted by aphids and the scale insects sucking juices from young shoots and leaves. Honeydew can be collected in two ways. The first one is direct collection from plants, while the second one-collecting from aphids 
Table $3{ }^{210}$ Po concentration and annual effective dose from the honey consumption in honey samples taken from plants (other and rosids) of KuyavianPomeranian Voivodeship (KP), Podlaskie Voivodeship (PD), Warmian-Masurian Voivodeship (WM) and West Pomeranian Voivodeship (WP)

\begin{tabular}{|c|c|c|c|c|c|c|c|}
\hline \multirow[t]{3}{*}{ Kind of honey } & \multirow[t]{3}{*}{$\mathrm{n}$} & \multicolumn{3}{|c|}{${ }^{210}$ Po concentration $\left(\mathrm{Bq} \mathrm{kg}^{-1}\right)$} & \multicolumn{3}{|c|}{ Effective dose $\left(\mu \mathrm{Sv}\right.$ year $\left.{ }^{-1}\right)$} \\
\hline & & \multicolumn{2}{|l|}{ Value } & \multirow[t]{2}{*}{ Mean \pm SD } & \multicolumn{2}{|l|}{ Value } & \multirow[t]{2}{*}{ Mean \pm SD } \\
\hline & & Min & Max & & Min & Max & \\
\hline \multicolumn{8}{|c|}{ Kuyavian-Pomeranian Voivodeship } \\
\hline Other & 13 & 0.009 & 0.067 & $0.028 \pm 0.018$ & 0.007 & 0.049 & $0.021 \pm 0.013$ \\
\hline Rosids & 2 & 0.050 & 0.060 & $0.055 \pm 0.007$ & 0.037 & 0.044 & $0.041 \pm 0.005$ \\
\hline \multicolumn{8}{|c|}{ Podlaskie Voivodeship } \\
\hline Other & 8 & 0.013 & 0.038 & $0.026 \pm 0.008$ & 0.010 & 0.028 & $0.019 \pm 0.006$ \\
\hline Rosids & 5 & 0.034 & 0.046 & $0.040 \pm 0.005$ & 0.025 & 0.034 & $0.029 \pm 0.004$ \\
\hline \multicolumn{8}{|c|}{ Warmian-Masurian Voivodeship } \\
\hline Other & 10 & 0.012 & 0.078 & $0.031 \pm 0.022$ & 0.009 & 0.057 & $0.023 \pm 0.016$ \\
\hline Rosids & 7 & 0.035 & 0.094 & $0.058 \pm 0.020$ & 0.026 & 0.082 & $0.045 \pm 0.019$ \\
\hline \multicolumn{8}{|c|}{ West Pomeranian Voivodeship } \\
\hline Other & 16 & 0.011 & 0.046 & $0.029 \pm 0.011$ & 0.008 & 0.034 & $0.021 \pm 0.008$ \\
\hline Rosids & 23 & 0.064 & 0.079 & $0.072 \pm 0.008$ & 0.014 & 0.058 & $0.040 \pm 0.023$ \\
\hline
\end{tabular}

$n$ quanity of samples

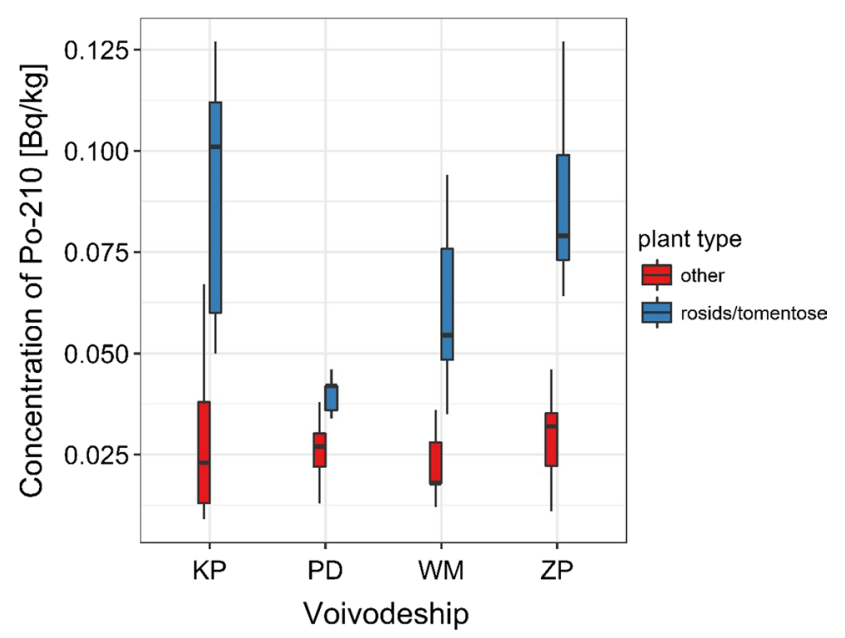

Fig. $3{ }^{210} \mathrm{Po}$ concentration in honey samples taken from plants (other and rosids) of Kuyavian-Pomeranian Voivodeship (KP), Podlaskie Voivodeship (PD), Warmian-Masurian Voivodeship (WM) and West Pomeranian Voivodeship (WP)

biting into plants and excreting also honeydew. This may suggest that aphids and the scale insects may have some effect on higher concentrations of ${ }^{210} \mathrm{Po}$.

The results of ${ }^{210} \mathrm{Po}$ concentration and effective annual dose from honey consumption in KuyavianPomeranian Voivodeship were presented in Table 1. The ${ }^{210} \mathrm{Po}$ concentration in this province was between $0.009 \pm 0.001$ and $0.208 \pm 0.011 \mathrm{~Bq} \mathrm{~kg}{ }^{-1}$ (with the average value $0.092 \pm 0.067 \mathrm{~Bq} \mathrm{~kg}^{-1}$ ), while values of effective annual dose from honey consumption ranged from $0.007 \pm 0.001$ to $0.152 \pm 0.008 \mu \mathrm{Sv}$ year $^{-1}$ (with the average value $0.067 \pm 0.049 \mu \mathrm{Sv}$ year $\left.{ }^{-1}\right)$. The average ${ }^{10} \mathrm{Po}$ concentrations and effective annual dose from honey consumption were higher for industrial areas of this province $\left(0.156 \pm 0.031 \mathrm{~Bq} \mathrm{~kg}^{-1}\right.$ and $0.114 \pm 0.023 \mu \mathrm{Sv}_{\text {year }}{ }^{-1}$ respectively) than for non-industrial areas $\left(0.052 \pm 0.050 \mathrm{~Bq} \mathrm{~kg}^{-1}\right.$ and $0.038 \pm 0.036 \mu \mathrm{Sv}$ year $^{-1}$ respectively) (Table 2, Fig. 2). The higher values of ${ }^{210} \mathrm{Po}$ concentrations and effective dose (between $0.101 \pm 0.010$ and $0.199 \pm 0.012 \mathrm{~Bq} \mathrm{~kg}^{-1}$ and between $0.074 \pm 0.007$ and $0.146 \pm 0.009 \mu \mathrm{Sv}_{\text {year }}{ }^{-1}$ were measured in this region around salt mine "Solina" (where the salt is obtained as a result of leaching) within which there are: borehole mine of salt "Mogilno" in Przyjma and borehole mine of salt "Góra" in Radojewice. Additionally, the stage of reconnaissance works was completed in Lubień Kujawski and the boreholes confirmed the presence of salt. In 2018, the construction of a salt mine will commence, and it is planned to be completed in 2020. The obtained results of ${ }^{210} \mathrm{Po}$ concentration in this mining area are smaller than the results of ${ }^{210} \mathrm{Po}$ concentration around the mining area in Lower Silesian Voivodeship and Lesser Poland Voivodeship [27, 28]. Moreover, in this region there are active plants, where salt is obtained as a result of evaporation of underground brine: "Ciech Soda Polska S. A." plant in Inowrocław-Mątwy and Janikowo and the saltern in Ciechocinek. It should be remembered, however, that the "Ciech Soda Polska" plant places strong emphasis on environmentfriendly solutions.

Based on the results obtained for Pomeranian, West Pomeranian and Kuyavian-Pomeranian voivodeships, it can be concluded that apiaries located near polluted areas (taking into account heavy traffic, industrial contaminants) can be helpful in monitoring the radionuclides levels from various sources. In West Pomeranian, Pomeranian and Kuyavian-Pomeranian Voivodeships the reason of higher 
${ }^{210}$ Po concentration might be well-developed industry and location of apiaries near the sources of pollution. In contrast, honeys from Warmian Masurian and Podlaskie voivodeships showed lower contents of ${ }^{210}$ Po than did the other honeys, due to the fact that these regions are not industrially polluted.

Heoneybees and their products can be considered as bioindicators because honeybees are exposed to contaminants present in environment around apiary [1, 29]. The honeybee's collects nectar and pollen from locations that are situated up to about $3 \mathrm{~km}$ from apiary. Because of this large surface area that honeybees and their products have been proposed as suitable bioindicators of chemical pollution [1, 29-32]. Taking into account kind of honey, our obtained results of ${ }^{210}$ Po concentration in honey samples for all analyzed provinces show, that the highest concentrations were measured in honeydew samples (between $0.058 \pm 0.003$ and $0.238 \pm 0.006 \mathrm{~Bq} \mathrm{~kg}^{-1}$ (with the average value $0.125 \pm 0.047 \mathrm{~Bq} \mathrm{~kg}^{-1}$ ), while smaller values were found in nectar honey samples (from $0.011 \pm 0.001$ to $0.198 \pm 0.006 \mathrm{~Bq} \mathrm{~kg}^{-1}$ (with the average value $0.043 \pm 0.033 \mathrm{~Bq} \mathrm{~kg}^{-1}$ ) (Table 1, Fig. 4). The obtained results show, that honey samples, due to their ability to accumulate the natural isotope ${ }^{210} \mathrm{Po}$, meet all the requirements that are put to good bioindicators, and especially honeydew honey, which accumulates about 3 times more of this radionuclide than other nectar honeys. Values of the estimated annual effective dose from honey consumption ranged from $0.042 \pm 0.002$ to $0.174 \pm 0.004 \mu \mathrm{Sv}$ year $^{-1}$ and from $0.008 \pm 0.001$ to $0.145 \pm 0.004 \mu \mathrm{Sv}$ year $^{-1}$ for honeydew samples and nectar samples respectively (Table 2). The average annual effective dose from honey consumption was $0.091 \pm 0.035 \mu \mathrm{Sv}$ year $^{-1}$ for honeydew samples and $0.031 \pm 0.024 \mu \mathrm{Sv}$ year ${ }^{-1}$ for nectar honeys samples (Table 1). The presented work shows significant variations

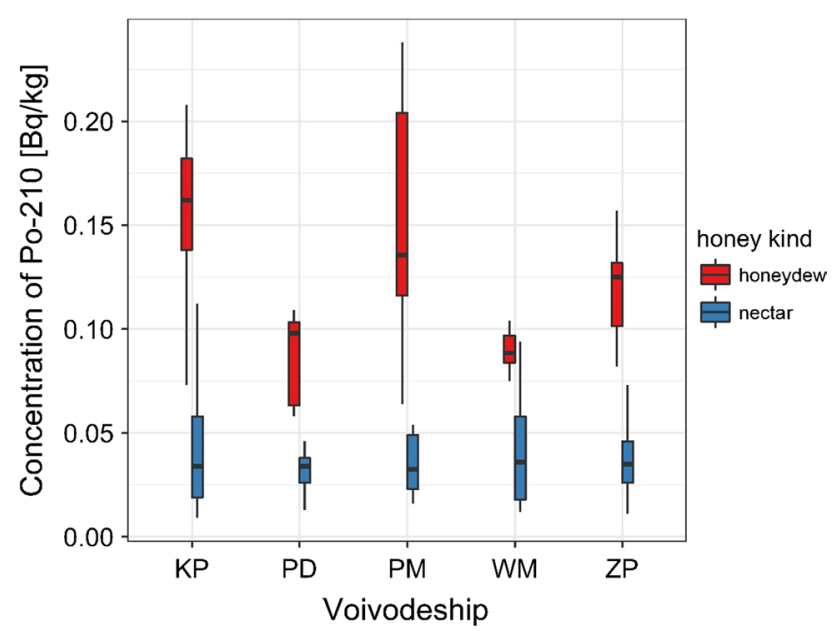

Fig. $4{ }^{210}$ Po concentration in nectar and honeydew honey samples in analyzed voivodeships in the values of ${ }^{210} \mathrm{Po}$ in different Polish voivodeships so we can conclude that honey can be a reliable biological marker for the assessment of radionuclides pollution.

On the other hand taking into account kind of honey and type of plants from which bees have been collecting pollen or nectar our obtained results of ${ }^{210} \mathrm{Po}$ concentration in honey samples for all analyzed provinces show, that the highest concentrations were measured in honeydew samples, higher in honey samples from plants tomentose covered and/ or belonging to rosids clade and the smallest in other honey samples (Fig. 5).

Based on ANOVA analysis significant statistical differences were found between the concentration of polonium in honey samples in industrial and non-industrial areas of West Pomeranian Voivodeship, Pomeranian Voivodeship and Kuyavian-Pomeranian Voivodeship ( $\mathrm{p} \ll 0.05$ ). The statistically significant differences were observed also for honeydew and nectar samples of honey for all analyzed voivodeships ( $\mathrm{p} \ll 0.05)$. Significant statistical differences were found for Podlaskie Warmian-Masurian, West Pomeranian and Kuyavian-Pomeranian Voivodeships between kind of honey and morphological structure of plants from which bees collected nectar (tomentose and its lack) $(\mathrm{P} \ll 0.05)$.

The obtained in this study values of ${ }^{210} \mathrm{Po}$ concentrations in honey samples are much smaller than the values for other voivodeships of southern Poland (e.g. the average ${ }^{210} \mathrm{Po}$ concentration was $0.621 \pm 0.832 \mathrm{~Bq} \mathrm{~kg}^{-1}$ for Lesser Poland Voivodeship and $0.777 \pm 1.711 \mathrm{~Bq} \mathrm{~kg}^{-1}$ for Lower Silesian Voivodeship) [27, 28]. Average effective dose from the consumption of honeys from analyzed voivodeships is smaller than the average effective dose from natural sources, which is $2.4 \mathrm{mSv}$ and from the average annual effective dose associated with the absorption of radioactive radionuclides $(90 \mu \mathrm{Sv})[33,34]$. This allows us to believe that eating honey

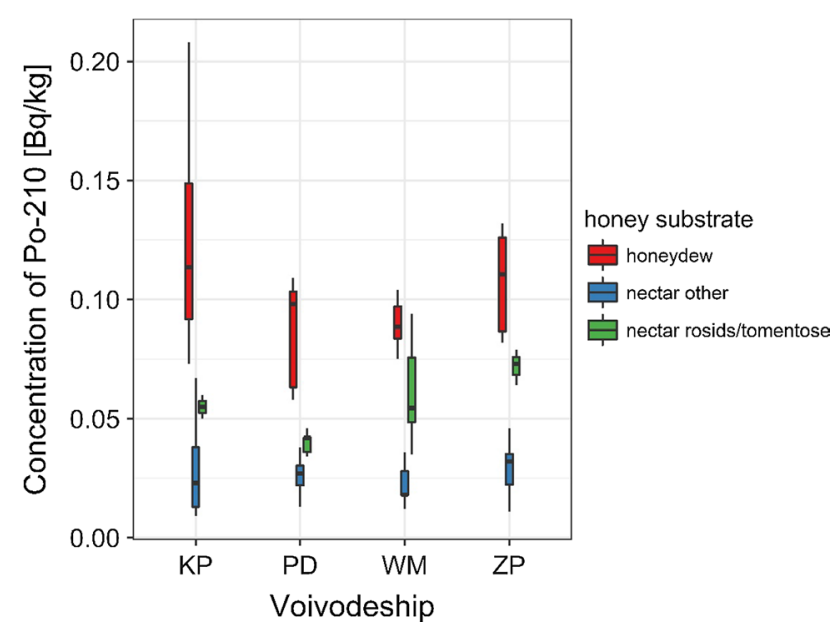

Fig. $5{ }^{210}$ Po concentration in analyzed honey samples taking into account honey substrate 
from the analyzed voivodeships is safe and does not constitute a radiological threat.

\section{Conclusions}

The results of polonium $\left({ }^{210} \mathrm{Po}\right)$ determination in different environmental honey samples collected in northern Poland are presented and discussed in this paper. The polonium content in honey samples was measured by alfa-spectrometer technique. The ${ }^{210}$ Po concentrations in honey samples from West Pomeranian Voivodeship, Pomeranian Voivodeship and Kuyavian-Pomeranian Voivodeship recorded in this study are higher than the contents of ${ }^{210} \mathrm{Po}$ from WarmianMasurian Voivodeship and Podlaskie Voivodeship. The results of the presented survey suggest that honey can be a good indicator of polonium contamination of the environment. Higher ${ }^{210}$ Po concentrations were found in three voivodeships, which is connected with the development of many branches of industry (e.g. chemical industry, petrochemical and sodium industry, as well as fertilizer industry). It also seems that a type of plant from which bees have been collecting pollen or nectar may have some effect on the bioaccumulation of this radionuclide. The present results also proved that honeydew honey contains more polonium than nectar honey. The results showing concentration of ${ }^{210} \mathrm{Po}$ in honey samples from analyzed voivodeships obtained in this study can lead to the conclusion that consumption of honey is safe and does not adversely affect human health.

Acknowledgements The authors would like to thank the Ministry of Science and Higher Education for the financial support of this work under Grant DS/530-8635-D745-18. The authors would also like to thank all those who contributed to the acquisition of research material.

Open Access This article is distributed under the terms of the Creative Commons Attribution 4.0 International License (http://creativeco mmons.org/licenses/by/4.0/), which permits unrestricted use, distribution, and reproduction in any medium, provided you give appropriate credit to the original author(s) and the source, provide a link to the Creative Commons license, and indicate if changes were made.

\section{References}

1. Tuzen M, Silici S, Mendil D, Sovlak M (2007) Trace element levels in honeys from different regions of Turkey. Food Chem 103:325-330

2. Isajenko K, Piotrowska B, Fujak M, Kardaś M (2011) Radiation Atlas of Poland. Central Laboratory for Radiological Protection, BMŚ, Warszawa

3. Aazouazi M, Quahidi Y, Fakhi S, Anders Y, Abbe JCh, Benmansour M (2001) Natural radioactivity in phosphates, phosphogypsum and natural waters in Morocco. J Environ Radioact $54: 231-242$
4. Meinrath A, Schneider P, Meinrath G (2003) Uranium ores and depleted uranium in the environment, with a reference to uranium in the biosphere from the Erzgebirge/Sachsen, Germany. J Environ Radioact 2(3): 175-193

5. Carvalho FP, Oliveira JM (2010) Uranium isotopes in the Balkans environment and foods following the use of depleted uranium in the war. Environ Int 36:352-360

6. Boryło A, Skwarzec B, Olszewski G (2012) The radiochemical contamination $\left({ }^{210} \mathrm{Po}\right.$ and $\left.{ }^{238} \mathrm{U}\right)$ of zone around phosphogypsum waste heap in Wiślinka. J Environ Sci Heal A 47:675-687

7. Boryło A, Nowicki W, Skwarzec B (2013) The concentrations of trace metals in selected cultivated and meadow plants collected from phosphogypsum stack in Wiślinka, northern Poland. Pol J Environ Stud 22(2):347-356

8. Boryło A, Olszewski G, Skwarzec B (2013) A study on lead $\left({ }^{210} \mathrm{~Pb}\right)$ and polonium $\left({ }^{210} \mathrm{Po}\right)$ contamination from phosphogypsum in the environment of Wiślinka (northern Poland). Environ Sci Process Impacts 15:1622-1628

9. Meli MA, Desideri D, Roselli C, Feduzi L, Benedetti C (2016) Radioactivity in honey of the central Italy. Food Chem 202:349-355

10. Eisenbud M (1987) Environmental radioactivity, 3rd edn. Academic Press, San Diego

11. Olszewska-Wasiołek M (1995) Estimates of the occupational radiological hazard in the phosphate fertilizers industry in Poland. Radiat Prot Dosim 58:269-276

12. Hedvall R, Erlandson B (1996) Radioactivity concentrations in non-nuclear industries. J Environ Radioact 32:19-31

13. Righi S, Lucialli P, Bruzza L (2005) Health and environmental impacts of a fertilizer plant. Part I. Assessment of radioactive pollution. J Environ Radioact 82:167-182

14. Righi S, Lucialli P, Bruzza L (2005) Health and environmental impacts of a fertilizer plant. Part II. Assessment of radioactive pollution. J Environ Radioact 82:183-198

15. Skwarzec B, Boryło A, Kosińska A, Radzajewska S (2010) Polonium $\left({ }^{210} \mathrm{Po}\right)$ and uranium $\left({ }^{234} \mathrm{U},{ }^{238} \mathrm{U}\right)$ in water, phosphogypsum and their bioaccumulation in plants around phosphogypsum waste heap in Wiślinka (northern Poland). Nukleonika 2(55):187-195

16. Skwarzec B, Jahnz-Bielawska A, Boryło A (2010) The inflow of uranium ${ }^{234} \mathrm{U}$ and ${ }^{238} \mathrm{U}$ from the Vistula River catchment area to the Baltic Sea. Radiochim Acta 98:367-375

17. Skwarzec B, Tuszkowska A, Boryło A (2010) The inflow of uranium ${ }^{234} U$ and ${ }^{238} U$ from the Odra River catchment area to the Baltic Sea. Oceanologia 52(4):1-21

18. Skwarzec B, Strumińska-Parulska DI, Boryło A, Kabat K (2012) Polonium, uranium and plutonium radionuclides in aquatic and land ecosystem of Poland. J Environ Sci Heal A 47:479-496

19. Boryło A, Skwarzec B (2011) Bioaccumulation of polonium $\left({ }^{210} \mathrm{Po}\right)$ and uranium $\left({ }^{234} \mathrm{U},{ }^{238} \mathrm{U}\right)$ in plants around phosphogypsum waste heap in Wislinka (northern Poland). Radiochim Acta 99:1-13

20. Boryło A, Nowicki W, Olszewski G, Skwarzec B (2012) Polonium $\left({ }^{210} \mathrm{Po}\right)$, uranium $\left({ }^{234} \mathrm{U},{ }^{238} \mathrm{U}\right)$ isotopes and trace metals in mosses from Sobieszewo Island, northern Poland. J Environ Sci Heal A 47:1831-1842

21. Boryło A, Nowicki W, Skwarzec B (2009) Isotopes of polonium ${ }^{210} \mathrm{Po}$, uranium ${ }^{234} \mathrm{U}$ and ${ }^{238} \mathrm{U}$ for industrialized areas in Poland (Wiślinka). Int J Environ Anal Chem 89(8-12):677-685

22. Olszewski G, Boryło A, Skwarzec B (2016) The radiological impact of phosphogypsum stockpile in Wiślinka (northern Poland) on the Martwa Wisła river water. J Radioanal Chem 307:653-660

23. Olszewski G, Boryło A, Skwarzec B (2016) A study on possible use of Urtica dioica (common nettle) plants as uranium $\left({ }^{234} \mathrm{U}\right.$, ${ }^{238} \mathrm{U}$ ) contamination bioindicator near phosphogypsum stockpile. J Radioanal Chem 308:37-46 
24. Dupuis C (1984) Willi Hennig's impact on taxonomic thought. Annu Rev Ecol Syst 15:1-24

25. Scotland RW, Wortley AH (2003) How many species of seed plants are there? Taxon 52(1):101-104

26. Wang H, Michael MJ, Soltis PS, Bell ChD, Brockington SF, Alexandre R, Davis ChC, Latvis M, Manchester SR, Soltis DE (2009) Rosid radiation and the rapid rise of angiosperm-dominated forests. Proc Natl Acad Sci 106(10):3853-3858

27. Boryło A, Romańczyk G, Skwarzec B (2017) Honey as bioindicator of Lesser Poland and Lower Silesian Voivodeships. In: International conference on developments and applications of nuclear technologies, Kraków, Poland, 10-13 Sep 2017

28. Boryło A, Skwarzec B, Romańczyk G, Szymańska M (2017) Radiochemiczne tajemnice miodów pozyskanych z województw dolnośląskiego i małopolskiego, II Ogólnopolska Konferencja Naukowa "Transformacja zanieczyszczeń w środowisku", Kraków, 14-15 Dec 2017 (in Polish)
29. Conti ME, Botre F (2001) Honeybees and their products as potential bioindicators of heavy metals contamination. Environ Monit Asses 69:267-282

30. Raes H, Cornelis R, Rzeznik U (1992) Distribution, accumulation and depuration of administered lead in adult honeybees. Sci Total Environ 113:269-279

31. Crane E (1984) Bees, honey and pollen as indicators of metals in the environment. Bee World 65(1):47-49

32. Leita L, Muhlbachova G, Cresco S, Barbattini R, Mondini C (1996) Investigation of the use of honeybees and honey bee product to assess heavy metals contamination. Environ Monit Assess 43:1-8

33. Bem H (2005) Radioaktywność w środowisku naturalnym. PAN Komisja Ochrony Środowiska, Łódź. ISBN 978-8-3864-9235-05

34. UNSCEAR (2000) United Nations Scientific committee on the effects of atomic radiation, vol 1. United Nations, New York. ISBN 92-1-142239-6 